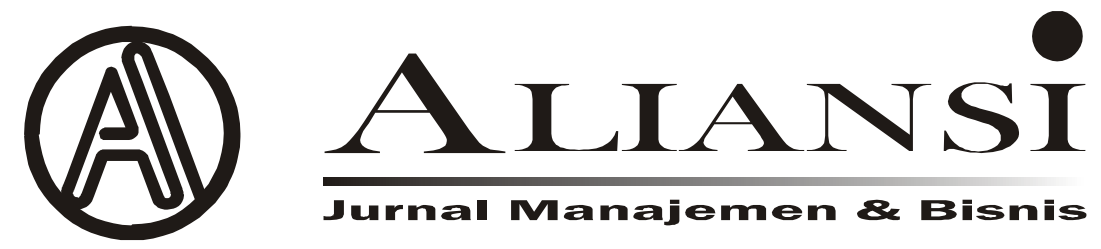

\title{
MANFAAT KEBERADAAN SUMUR BOR TERHADAP USAHA MIKRO KECIL DAN MENENGAH (UMKM) IMPLIKASINYA PADA PEMBANGUNAN EKONOMI DI DUSUN SURUH
}

\author{
Oleh : Widodo dan Dede Mulyana \\ email : munir.azhari@gmail.com; ddmcikeas2@gmail.com
}

\begin{abstract}
Through this research, the authors have general goals and specific objectives, namely as follows: In general, with respect to the problems described above, the purpose of this study is to find out how the benefits of the existence of drilled wells on Micro, Small and Medium Enterprises (MSMEs) and its implications for Economic Development in Suruh Hamlet, Hargomulyo Village, Kepanewonan Gedangsari, Gunungkidul Regency. In particular, this research is to obtain information regarding the welfare of the people after the drilling well was found in Suruh Hamlet, Hargomulyo Village, Gedangsari District, Gunungkidul Regency." "Types and research designs can be grouped according to research objectives. This research is classified as descriptive research, namely research that is descriptive of something that happens to the object. "Based on the results of the analysis, it was found that the existence of a drilled well in Suruh Hamlet is very beneficial for MSMEs and its implications for economic development because Suruh Hamlet is a barren hamlet that relies on rainwater and often lacks water during the dry season, so that both agricultural land, plantations and Other natural aquaculture requires water produced from drilled wells as a substitute for rainwater when the dry season falls. "The suggestions that can be conveyed by the author are related to the results of research on MSMEs and their implications for the economy, namely: With the drill well, MSME actors can make the best use of it so that the drill wells provided by investors and donors can really developing MSMEs in Suruh Hamlet, the economy will develop better. Hopefully, in Dusun Suruh there will be more Drilling Wells made by investors or proponents so that Dusun Suruh can be supplied with irrigation by using Drilled Wells so that MSMEs in the hamlet can increase and progress, so that Economic Development will be achieved more quickly. "Keywords: Drilling Well, Micro, Small and Medium Enterprises (MSMEs) and Economic Development
\end{abstract}

\section{PENDAHULUAN}

Pembangunan Ekonomi di Dusun Suruh, Desa Hargomulyo, Kepanewonan Gedangsari, Kabupaten Gunungkidul, Daerah Istimewa Yogyakarta perlu menjadi perhatian serius, karena pada dasarnya bahwa pangan lokal berupa ketela pohon, ubi jalar, labu kuning, sukun, pisang, uwi, dan umbi-umbian lain merupakan cadangan makanan yang potensial mengatasi krisis pangan. Akan tetapi, masyarakat semakin meninggalkan pangan lokal contohnya tiwul (dengan bahan baku ketela pohon), terutama di Dusun Suruh, Hargomulyo, Gedangsari, Gunungkidul. Seperti yang telah diteliti oleh Anna Susilaningtyas, peneliti Lembaga Konsumen Yogyakarta, mengemukakan, berdasarkan penelitian di tiga wilayah di Gunung Kidul, pola makan masyarakat terutama yang tinggal di dekat perkotaan telah bergeser. "makanan pokok berupa tiwul masih ada. Namun, saat memasak tiwul, dirasakan belum cukup dan tetap harus memasak nasi sehingga merasa bekerja dua kali. Akhirnya mereka lebih memilih memasak nasi saja sehingga semakin jarang memasak tiwul," ujar Anna, Kamis (8/10) di Yogyakarta. Penelitian soal tiwul dilakukan di Gangsalan Lor, Nglindur, Girisubo; Dusun Suruh, Hargomulyo, Gedang Sari; dan Desa Mulo, Wonosari. "Meskipun Gunung Kidul sentra gaplek, masyarakatnya saat ini pengonsumsi nasi," katanya. Menurut Anna, gaya hidup dan penilaian soal "status" pengonsumsi tiwul memengaruhi bagaimana masyarakat memperlakukan pangan lokal itu. Terlebih anggapan di masyarakat mengatakan, mereka yang mengonsumsi tiwul statusnya lebih rendah dari yang mengonsumsi nasi. Kepala Pusat Kajian Makanan Tradisional Universitas Gadjah Mada Murdijati Gardjito menyatakan, pangan lokal adalah bahan pangan yang diproduksi oleh masyarakat di tempat mereka tinggal seperti ketela pohon, ubi jalar, labu kuning, sukun, pisang, uwi, dan umbi-umbian lainnya. "Karena tumbuh di lingkungan 
sekitar tempat tinggal, pangan lokal merupakan cadangan makanan yang potensial untuk mengatasi krisis pangan," paparnya, saat berbicara dalam lokakarya ketahanan pangan. Tak lagi kenal Meski potensinya besar, saat ini sebagian besar warga tidak lagi mengenal pangan lokal di daerahnya. Bahkan, berdasarkan sebuah survei, pangan lokal hanya dikenal oleh 20 persen masyarakat. Tanpa upaya berarti, pangan lokal yang potensial ini semakin terlupakan. Gardjito menuturkan, upaya memopulerkan pangan lokal harus dilakukan dengan mengolahnya menjadi makanan bermutu, diterima generasi muda. Untuk merubah tardisi di wilayah suruh memerlukan terobosan baru karena wilayah yang serba kekurangan air maka diperlukan usaha untuk menyediakan air pada wilayah tersebut, terobosan berikutnya adalah ditingkatkannya Usaha Mikro kecil menengah (UMKM) sehingga beriplikasi pada Pembangunan Ekonomi

Dikarenakan bahan baku untuk memunculkan Usaha Mikro Kecil Menengah (UMKM) telah berada di wilayah Suruh sendiri maka perlu di kembangkan atau diperbaharui bahan baku tersebut, bahan baku dimaksud adalah hasil perkebunan yaitu kelapa, pisang, rambutan, pete, salak, manga dan lada, kemudian hasil perikanan, selanjutnya hasil pertanian yaitu padi, kacang, jagung, kedelai, singkong, dan ganyong. Ada juga hasil peternakan yaitu sapi, kambing, dan ayam. Juga terdapat hasil hutan yang terdiri dari kayu jati, mahoni, sengon dan lain sebagainya. Dengan kondisi tanah yang sering mengalami kekeringan maka diperlukan suber air. terobosan pertama telah diawali oleh Marsinem, S.Sos. M.Si. yang bersangkutan adalah penduduk asli Suruh yang telah menimba ilmu di wilayah lain dan menjadi dosen di Wilayah Jawa Timur. Dengan kepeduliannya tersebut maka telah diadakannya sumur bor dengan tujuan untuk mengairi wilayah Suruh yang berpoensi sebagai penghasil bahan baku untuk Usaha Mikro Kecil Menengah (UMKM). Bidang Usaha Mikro Kecil menengah yang berpotensi dengan bahan baku dari wilayah Suruh diantaranya adalah Tempe, Tahu, batu nisan, meubel, anyaman bambo, gilingan padi, dan kerajinan kayu. Dengan begitu pembangunan ekonomi akan cepat tercapai.

\section{Tujuan Penelitian}

Melalui penelitian ini, penulis mempunyai tujuan umum dan tujuan khusus, yaitu sebagai berikut :

Secara Umum, berkenaan dengan masalah yang diuraikan di atas, tujuan dari penelitian ini adalah Untuk mengetahui bagaimana manfaat keberadaan sumur bor terhadap Usaha Mikro Kecil Menengah (UMKM) sehingga berimplikasi pada Pembanguan Ekonomi di Pedukuhan Suruh, Desa Hargomulyo, Kepanewonan Gedangsari, Kabupaten Gunungkidul.

Secara Khusus, penelitian ini untuk memperoleh informasi mengenai Pembangunan Ekonomi setelah dibuat sumur bor di pedukuhan Suruh, Desa Hargomulyo, Kepanewonan Gedangsari, Kabupaten Gunungkidul.

\section{TELAAH LITERATUR DAN PENGEMBANGAN PROPOSISI.}

Pengertian "Manfaat" menurut Kamus Besar Bahasa Indonesia adalah : "guna atau faedah, laba atau untung". Dari pengertian di atas maka dapat dikatakan bahwa manfaat-manfaat yang diperoleh itu tentunya akan menyebabkan perubahan terhadap suatu fungsi tertentu dalam suatu pranata.

Setiap orang pastinya membutuhkan ketersediaan air untuk hidupnya. Karena seperti yang diketahui bahwa air sangat dibutuhkan untuk berbagai kepentingan. Hal tersebutlah yang kemudian banyak orang yang lantas membuat tempat sebagai sumber air. Salah satunya yang paling termudah adalah dengan membuat sumur. Namun seperti yang diketahui bahwa sumur untuk kali ini tidak terdiri dari satu jenis semata. Karena sudah banyak yang tahu pada masa lampau, sumur hanya dikenal dengan jenis sumur gali. Yakni sumur yang dibuat dengan cara sederhana dan juga dibuat tanpa kerepotan yang terlalu banyak. Jenis sumur yang nyatanya masih dipilih oleh banyak orang. Namun tentu dengan kemajuan jaman maka berbagai pemilihan juga ikut berkembang. Salah satunya dengan kehadiran dari sumur Bor. Bahkan bisa dibilang sudah banyak pihak yang lebih memilih sumur bor dibandingkan sumur gali. Namun bukan berarti hal tersebut lantas serta merta membuat banyak orang lantas percaya untuk membuat sumur bor. Padahal ada 4 manfaat utama sumur bor dibandingkan sumur gali. Jumlah manfaat yang tentunya tidak bisa dipandang sebelah mata begitu saja. Sehingga bagi mereka yang masih ragu untuk memilih antara membuat sumur bor atau sumur gali maka ada baiknya untuk mengetahui manfaat dari sumur bor seperti berikut ini:

Manfaat Utama Sumur Bor Dibandingkan Sumur Gali. Manfaat pertama yang dimiliki dari membuat sumur bor ketimbang memilih sumur gali adalah proses pembuatannya yang lebih cepat. Dimana yang hal ini tentunya dapat dimaklumi apabila melihat proses pembuatan dari sumur Bor sendiri. Seperti yang diketahui bahwa Sumur Bor dibuat dengan 
mesin. Sangat berbanding terbalik dengan pembuatan Sumur Gali yang masih menggunakan teknik konvensional maupun sederhana. Maka dengan pembuatan dan pemilihan mesin tentunya akan otomatis membuat sumur tersebut akan menjadi lebih mudah dari biasanya. Dan apabila lebih mudah tentunya akan membuat proses pembuatan sumur tersebut akan menjadi lebih cepat. Dimana banyak pengalaman yang membuktikan bahwa pembuatan Sumur Bor hanya memakan waktu sebanyak satu hari atau paling maksimal yakni hanya dua hari. Sebuah rentang pembuatan yang tentunya terbilang cepat. Apalagi apabila lokasi pembuatan sumur bor tersebut terbilang mendukung dan juga strategis. Maka sudah dapat dipastikan bahwa hal tersebut akan membuat proses pembuatan sumur bor menjadi lebih cepat. Sesuatu yang tentunya akan sangat berbanding terbalik apabila dibandingkan dengan pembuatan sumur gali. Seperti yang diketahui bahwa pembuatan sumur gali membutuhkan waktu yang tidak sebentar. Dimana hal ini tentunya akan membuat banyak waktu yang terbuang. Sesuatu yang pastinya tidak ingin dirasakan oleh setiap orang. ( ht t p s:// www.youtube.com) watch? $v=$ XnbETifRhxo)

Manfaat Utama Sumur Bor Dibandingkan Sumur Gali. Manfaat berikutnya dari membuat Sumur Bor dibandingkan sumur gali adalah tidak memakan tempat yang berlebihan. Hal tersebut tentunya disebabkan karena pembuatan sumur bor mengandalkan mesin untuk bisa membuatnya. Maka hal ini akan membuat proses pembuatan dan peletakan alat tidak akan memakan banyak tempat. Sesuatu yang tentunya akan sangat berbanding terbalik dengan sumur gali. Seperti yang diketahui bahwa sumur gali membutuhkan banyak tempat untuk melancarkannya. Sesuatu yang pastinya akan sangat merepotkan bahkan tidak jarang merugikan. Karena pembuatan sumur gali akan memakan tempat yang sangat banyak. Sehingga bagi mereka yang ingin membuat sumur tanpa memakan tempat terlalu banyak maka sumur bor adalah pilihan terbaiknya. (https://www.youtube.com/watch?v=_LKed$z E s f O)$

Manfaat Utama Sumur Bor Dibandingkan Sumur Gali. Salah satu masalah paling utama yang seringkali dialami oleh mereka yang menggunakan sumur gali adalah terdapatnya limbah. Dimana limbah ini tentunya sangat tidak baik untuk sumur yang merupakan sumber air. Karena pastinya apabila terus dibiarkan akan berefek yang tidak baik untuk kesehatan. Dimana hal ini bisa dicegah apabila memilih menggunakan Sumur Bor. Karena yang perlu diketahui adalah bahwa sumur Bor tidak mudah tercemar. Hal tersebut tentunya bukan tanpa alasan. Karena sumur bor menggunakan Pipa PVC atau bisa juga menggunakan Pipa galvanis. Setelah pipa-pipa ini akan disambung secara teknik. Dimana kedua jenis pipa ini akan mencegah berbagai kotoran maupun limbah untuk bisa masuk. Hal tersebut tentunya disebabkan karena tidak adanya lubang di Sumur Bor untuk mencegah berbagai ha lasing untuk bisa masuk. Karena kelemahan dari sumur gali adalah memiliki banyak lubang resapan yang akan membuat kotoran maupun limbah menjadi mudah masuk karenanya. Sesuatu yang nantinya pasti akan merusak sumber air dari air di dalam sumur. Hal tersebut tentunya akan sangat merugikan bagi kesehatan. Karena apabila terus dibiarkan maka sumber air akan semakin buruk dari waktu ke waktu. (https:// accounts.google.com/b/0/AddMailService)

Manfaat Utama Sumur Bor Dibandingkan Sumur Gali. Manfaat terakhir yang dimiliki dengan memilih sumur Bor adalah lebih praktis digunakan. Karena banyak orang memiliki tempat tinggal dengan luas yang tidak terlalu dan seringkali berada di kawasan padat penduduk. Hal tersebutlah yang seringkali membuat banyak orang yang ragu untuk membuat sumur disana. Karena lokasi yang tidak terlalu luas tentunya ditakutkan tidak akan mampu menjadi tempat untuk sumur. Namun cerita akan menjadi lain apabila memilih Sumur Bor. Karena sumur bor lebih efeisien dan juga praktis sehingga tepat digunakan dimana saja. Terutama tempat yang sering mengalami kekeringan akan lebih mudah.

Keempat manfaat yang telah dijelaskan diatas tentunya bisa menjadi pertimbangan tersendiri bagi mereka yang masih ragu dalam memilih sumur bor. Tetapi ada beberapa orang pula yang tidak ingin disibukkan dengan hal yang sudah dijelaskan diatas, sehingga untuk meminimalisasi waktu, penggunaan profesional di bidang jasa pengeboran sumur adalah kuncinya.

Manfaat paling penting adalah bahwa keberadaan sumur bor tersebut dapat digunakan oleh masyarakat dalam rangka mengairi lahan tempat dibudidayakannya bahan baku untuk Usaha Mikro Kecil Menengah (UMKM). (UMKM) di dusun Suruh, Hargomulyo, Gedangsari, Gunungkidul membutuhkan bahan baku dari hasil kebun dan hasil hutan yang tentunya memerlukan pengairan, sehingga lahan tersebut tidak mengalami kekeringan

UMKM adalah roda penggerak perekonomian Indonesia. Ketika berbicara tentang bisnis dan 
ekonomi, apalagi tentang dunia usaha terkadang kita dihadapkan pada satu istilah yang sangat berperan terhadap perekonomian yaitu UMKM. Bahkan dari segi usaha pengelolaan, masih memiliki hubungan erat dengan perekonomian masyarakat di berbagai lapisan. Tetapi dalam bentuk usaha ekonomi yang non korporasi. Di Indonesia sendiri bidang usaha semacam ini pada tahun 2016 ke atas justru mengalami peningkatan. Ini menjadi bukti kalau masyarakat masih berminat untuk menjalankan usaha UMKM dengan baik.

Dalam perspektif usaha seperti yang dijelaskan di atas, maka lumrah jika ada pengamat yang menyamakan antara UMKM dengan UKM. Padahal jika dianalisis lebih mendetail sejatinya keduanya memiliki perbedaan yang sangat signifikan. Terutama jika peninjauan diarahkan pada segi lingkup usaha serta hukum yang menjadi regulasi keduanya.

Pengertian UMKM secara umum adalah singkatan dari Usaha Mikro Kecil dan Menengah. Yang mana ini merupakan satu model baru dalam kegiatan perniagaan atau perdagangan. Ada juga yang mengartikan bahwa UMKM adalah suatu usaha perniagaan yang pengelolaannya dilakukan oleh individu atau perorangan serta badan usaha dengan lingkup kecil yang lebih dikenal dengan istilah mikro.

Kriteria yang masuk UMKM pertama adalah usaha mikro. Yaitu suatu usaha atau perusahaan yang memiliki aset bersih usahanya kira-kira 50 juta perbulan. Biasanya untuk usaha jenis ini kekayaan yang berupa bangunan maupun perusahaan yang menjadi tempat usaha tidak masuk ke dalam kalkulasi. Selain itu usaha mikro memiliki ciri-ciri tertentu. Seperti belum pernah melakukan administrasi keuangan yang sistematis, sulit mendapat bantuan dari perbankan, barang yang dijual selalu berubah-ubah serta bentuk usahanya relatif kecil. Sedangkan contoh UMKM yang termasuk ke dalam kriteria usaha mikro adalah warung kelontong, peternak ayam, peternak lele, tukang cukur, dan warung nasi serta usaha yang sejenis. Di Suruh sebagian besar contoh usaha yang termasuk ke dalam kategori UMKM tidak terlalu banyak. Diantaranya adalah: Hasil Kehutanan, Hasil perkebunan, Hasil pertanian, Peternakan Perikanan, Kerajinan dan Industr kecil, Perdagangan, dan Perkembangan Ekonomi

Pembangunan Ekonomi pada umumnya didefinisikan sebagai suatu proses yang menyebabkan kenaikan pendapatan riil perkapita penduduk suatu Negara dalam jangka panjang yang disertai oleh perbaikan system kelemabagaan. Definisi lain menyebutkan bahwa pembangunan ekonomi merupakan suatu cabang dari ilmu ekonomi yang menganalisis masalah-masalah yang dihadapi olen Negara Sedang Berkembang (NSB) dan mencari cara-cara untuk mengatasi masalah-masalah itu agar Negara-negara tersebut dapat membangun ekonominya lebih cepat lagi (Lincolin Arsyad : 1999).

Pembangunan ekonomi tidak dapat secara sederhada diartikan dengan pertumbuhan ataupun industrialisasi, karena pembangunan ekonomi berarti pertumbuhan ditambah dengan terjadinya perubahanperubahan (growth plus change), karena adanya dimensi-dimensi kualitatif yang cukup penting dalam proses pembangunan tersebut. Disadari bahwa dalam proses pembangunan seringkali terjadi dampak ayng tidak diinginkan oleh masyarakat seperti ketimpangan dalam distribusi pendapatan, ketidakadilan dan kemiskinan.

Studi tentang pembangunan ekonomi telah menarik perhatian para ekonom sejak jama Kaum Merkantilis, Kaum Klasik sampai Marx dan Keynes. Ekonom Klasik, Adam Smith misalnya, telah menyinggung berbagai aspek tentang pembangunan ekonomi dalam bukunya yang sangat terkenal berjudul The Wealth of Nations (1776). Analisis-analisis mengenai masalah pembangunan yang dilakukan oleh para ekonom sekarang merupakan suatu kebangkitan kembali untuk memperhatikan masalah-masalah yang dianalisis para ekonom pada masa yang lalu.

Hargomulyo_SID\# Pemerintah Desa Hargomulyo pada hari ini Rabu 18 September 2019 telah melaksanakan Musyawarah Rencana Pembangunan Desa (MUSRENBANGDES). Musrenbangdes tahun ini antusiasme masyarakat tergolong cukup tinggi terlihat dari kehadiran mencapai $95 \%$, dari warga dan tokoh masyarakat yang di undang. dalam musyawarah ini yang menjadi prioritas adalah mengatasi permasalahan kekeringan di Desa Hargomulyo dalam rencana kegiatan di tahun 2020 mendatang. seperti yang disampaikan oleh camat Gedangsari dalam sambutannya " Mengatasi permasalahan kekeringan agar dimasukan dalam rencana kegiatan APBDES di tahun 2020, mengutamakan titik kekeringan yang terdapat sumber air di sekitarnya". https://www.hargomulyogedangsari.desa.id/first/artikel/137

Tahun 2017 Kalurahan Hargomulyo menerima Program Penyediaan Air Minum dan Sanitasi Berbasis Masyarakat (Pamsimas) tepatnya di Padukuhan Suruh. Pembangunan menggunakan dana APBN dan sharing dana dari Desa dan Masyarakat. Pembangunan berjalan lancar dengan sumber air 
menggunakan mata air yang ada di Padukuhan Suruh. Selama 2 tahun kegiatan berjalan lancar dan masyarakat merasa sangat gembira karena terlepas dari kekeringan. Akan tetapi mata air mengalami penurunan debit yang signifikan sejak pertengahan tahun 2019 sehingga tidak mampu mencukupi kebutuhan air minum masyar (http:// bappeda.gunungkidulkab.go.id/2021/01/berjuangmenyediakan-akses-air-minum-layak-di-kalurahanhargomulyo-kapanewon-gedangsari/)

Meier menyebutkan pembangunan ekonomi sebagai , .......

The process whereby the real per capita income of a country increases over a long period of time subject to the stipulations that the number below an absolute poverty line does not increase, and that the distribution of income doas nit become more unequal (Mansyuri dan Syarif Hidayat : Menyikapi Akar Persoalan Ketimpangan Ekonomi di Daerah : 2001:42),

Maksudnya adalah : "keberhasilan suatu pembangunan adalah pertumbuhan, adanya pemerataan dan peningkatan kesejahteraan masyarakatnya. Berarti pula bagi negara-negara miskin, konsep pembangunan ekonomi secara sederhana adalah suatu proses kebangkitan dari kemiskinan".

\section{Metodologi Penelitian}

Jenis dan rancangan penelitian dapat dikelompokkan sesuai tujuan penelitian, Penelitian ini tergolong penelitian deskriptif yaitu penelitian yang bersifat menjelaskan ssuatu yang terjadi pada objek.

\section{Sampel Penelitian}

Penentuan sumber data bergantung pada masalah yang akan diteliti. Pada penelitian ini yang menjadi sampel penelitian adalah sebanyak 33 (tiga puluh tiga) warga Dusun Suruh sebagai Investor atau penyandang dana pada proses pengeboran sumur di Dusun Suruh serta para pelaku Usaha Mikro Kecil dan Menengah (UMKM) yang dapat dihubungi dan dapat meberikan penjelasan mengenai manfaat Sumur Bor terhadap UMUM di Dusun Suruh.

\section{Operasionalisasi Variabel}

Dalam penelitian ini: Variabel sebab adalah Sumur Bor dan variable akibat adalah Usaha Mikro Kecil dan Menengah (UMKM) serta implikasinya terhadap Pembangunan Ekonomi, proses Sumur Bor dibuat serta manfaat terhadap Usaha Mikro Kecil dan
Menengah (UMKM), Juga Implikasi (keadaan) pembangunan Ekonomi.

\section{Metode Analisis}

Penelitian ini akan menggunakan alat analisis: Kualitas data penelitian sangat tergantung pada kualitas data yang dipakai didalam penelitian. Kualitas data penelitian ditentukan oleh instrumen yang digunakan untuk mengumpulkan data untuk menghasilkan data yang berkualitas. Instrumen penelitian yang baik harus memenuhi persyaratan yaitu valid dan reliabel. Untuk mengetahui valid atau tidaknya maka penulis disamping membaca literature yang telah didapat harus survei ke lapangan agar mengetahu kondisi nyata atau riil di lapangan.

\section{HASIL DAN PEMBAHASAN \\ Hasil Penelitian}

Dusun Suruh yang terletak diantara sebelah utara berbatasan dengan Desa Watugajah, sebelah timur berbatasan dengan Dusun Mangli, sebelah tenggara perbatasan dengan Dusun Jatibungkus, sebelah selatan berbatasan dengan Dusun Pace B, sebelah barat daya berbatasan dengan Dusun Suru Kidul, dan sebelah barat berbatasan dengan Dusun Suru Lor. Dusun Suruh hanya ada 1 (satu) Rukun Warga (RW) yang terdiri dari 8 (delapan) Rukun Tetanggan (RT). Pada saat ini telah ada Sumur Bor baru di Mereng Ngulon yang di prakarsai oleh Ibu Marsinem, S. Sos., M.Si, beliau adalah seorang Dosen dari STIA Banyuangga Bondowoso, Jawa Timur. Sedang dalam proses adalah Sumur Bor yang ada di Dok Lo lahan dari Bapak Sumadi, yang diprakarsai oleh Bapak Ketua Rukun Tetangga (RT). Sunaryo.

\section{Pembahasan}

Hasil bumi dan Usaha Mikro Kecil dan Menengah (UMKM) di Dusun Suruh yang berkaitan dengan adanya Sumur Bor diantaranya adalah:

Hasil Kehutanan, penghasil kayu jati, kayu sengon, kayu sono keling, kayu mahoni, dan bambu.

Kayu jati, tanaman yang biasanya dihasilkan dari hutan bisa ditanam di Suruh yaitu terutama kayu jati disamping masih ada kayu-kayu lainnya yang juga penting dan sangat bermanfaat, karena di Pedukuhan Suruh terdapat beberapa UMKM (pengrajin) dengan bahan baku Kayu Jati, dengan adanya sumur bur maka tanaman tanaman (kayu jati) yang masih kecil bisa hidup, karena ketika musim panas di Pedukuhan Suruh semua tanaman kering. 
Kayu sengon, bahwa jenis kayu ini sangat familier apabila digunakan sebagai papan, karena mengingat tumbuh dengan mudah dan juga rantingnya sering ditebang dan dijual sebagai kayu bakar yang mudah untuk digunakan pada industry rumah tangga.

Kayu Sono Keling banyak ditemukan di Dusun Suruh, kayu ini banyak ditanam dipinggiran lading sebagai perbatasan karena rantingnya sangat kuat dan sangat membantu terjadinya erosi serta daunnya juga bisa digunakan sebagai makanan ternak berupa hewan ternak kambing dan lembu.

Kayu mahoni banyak ditanam di Dusun Suruh, kayunya sangat keras sehingga sangat bagus apabila digunakan sebagai bahan pembuatan bahan bagunan dan kebutuhan rumah tangga, sehingga masyarakat Dusun Suruh sangat suka menanam kayu mahoni terebut, disamping sangan kuat untuk ketahanan tanah teras siring.

Bambu yang dihasilkan di Dusun Suruh sangat bagus dijadikan bahan baku untuk kerajinan masyarakat.

Hasil perkebunan: Kelapa, Pisang, Rambutan, Pete, dan Mangga. Kebun ini dalam waktu-waktu tertentu diairi air hasil sumur bor di wilayah Dusun Suruh;

1. Kelapa, sebagai bahan baku Pangan Industri Rumah Tangga (PIRT).

2. Pisang, sebagai bahan baku Pangan Industri Rumah Tangga (PIRT) berupa Kripik pisang dan pisang goring serta pisang rebus untuk dijual di warung-warung kecil.

3. Rambutan, bagi mereka yang panen rambutan dijual di pasar-pasar.

4. Pete, dijual di pasar-pasar tradisional.

5. Mangga, dijual di tokok buah.

Hasil pertanian: Padi, Jagung, Kacang, Singkong, Ganyong, dan Kedelai. Pertanian ini sangat memerlukan air agar tetap bertahan hidup dan hasil panen yang sesuai dengan harapan.

Padi, di Dusun Suruh petani padi sudah mulai berkurang karena lahan potensial padi sebagian besar sudah menjadi pemukiman dan berubah ditanami kayu jati, pete, dan jenis tanaman yang lebih menjanjikan hasilnya.

Jagung, akhir-akhir ini petani jagung cenderung memerlukan daunnya sebagai makanan ternak, karena secara ekonomi lebih mengungkan apabila dibanding dengan dipanen dalam bentuk jagung.

Kacang, di Dusun Suruh banyak ditanam kacang tanah yang hasilnya dijual ke saudagar atau tengkulak biasanya diborong di sawah. Sehingga tengkulak yang melakukan panen kacang tersebut, para petani tinggal menerima pembayaran secara borongan.

Singkong, pada sekitar tahun 1980-an kebun singkong di Dusun Suruh sangat terkenal karena bahan bakar singkong sanagt banyak digunakan sebagai makanan khas dusun tersebut diantaranya adalah: Thiwul dan Gathot. Seiring dengan perkembangan zaman maka singkong di Dusun Suruh mulai ditinggalkan warga masyarakat.

Ganyong, hasil kebun berupa ganyong sangat dibutuhkan pada industry kecil atau denis Usaha Kecil Mikro dan Menengah (UMKM) bahan baku ganyong dapat digunakan sebagai industry kecil Krecek Ganyong yang dalam prosesnya sangat banyak memerlukan air, oleh karena itu dengan adannya Sumur Bor di Dusun Suruh sangat bermanfaat bagi pembuat Krecek Ganyong. Krecek ganyong sampai saat ini merupakan makan paforit di Dusun Suruh, karena disamping bisa dijadikan bahan sayuran juga nikmat ketika digoreng sebagai pengganti krupuk pada umumnya.

Kedelai, tanaman ini menjadi bahan baku Usaha Mikro kecil dan Menengah (UMKM) di wilayah Suruh karena sebagian penduduk Suruh sebagai pelaku UMKM yaitu memproduksi tempe dan tahu. Oleh karena itu bahan baku yang dihasilkan sendiri dengan adanya sumur bur yang telah disediakan oleh warga Suruh maka bagi UMKM sangat bermanfaat. Karena tanaman kedelai bisa di airi sesuai kebutuhan sehingga tidak mengalami kekeringan dan bisa paen sesuai yang diharapkan maka pengusaha tahu dan tempe bisa membeli bahan baku dari warga yang menanam kedelai.

Peternakan: Sapi, Kambing, dan Ayam. Hewan ternak tersebut terutama sapi perlu dimandikan, karena di Dusun Suruh termasuk dusun yang kekuragan air maka sumur bor sangat bermanfaat dan membantu para peternak, apalagi kalau musim kemarau sangat sulit mendapatkan rumput dengan demikian dengan sumur bor maka makanan ternak datat ditanam dengan bantuan pegairan yang bersumber dari sumur bor.

Perikanan, di Dusun Suruh dapat diketemukan jenis ikan lele yang dibudidaya oleh masyarakat, ikan tersebut disetor ke wqrung-warung makan sehingga digunakan sebagai pelengkap Usaha kecil Mikro dan Menengah (UMKM) kelompok warung makan.

Kerajinan dan Industr kecil: Tempe, Tahu, Batu Ukir, Meubel, Anyaman Bambu, Gilingan Padi, dan Kerajinan kayu; 
1. Tempe, bahan baku tempe adalah kedelai yang tentunya dihasilkan dari para petani kedelai.

2. Tahu, dengan bahan baku kedelai yang dihasilkan dari petani di Dusun Suruh.

3. Batu ukir, dikerjakan oleh warga Dusun Suruh dengan bahan baku dari Dusun Suruh itu sendiri.

4. Meubel, dengn bahan baku dari kayu hasil hutan di Dusun Suruh.

5. Anyaman bambu, dapat dikerjakan oleh warga dengan bahan baku di dapat dari Hasil hutan di dusun Suruh.

6. Gilingan padi, menampung dan menggiling padi dari hasil petani warga setempat.

Pengrajin kayu, yang dilakukan oleh warga setempat tentunya dapat meningkatkan Usaha Mikro Kecil dan Menengah (UMKM).

Perdagangan: Toko Kelontong dan Warung Makan;

1. Toko kelontong yang berada pada dusun Suruh sangat membantu warga setempat melakukan transaksi sehingga perputaran ekonomi warga dapat berjalan dengan lancar.

2. Warung makan, yang berada di Dusun Suruh sangat membantu warga sehungga ekonomi warga di Dusun Suruh dapat berputar dengan lancar dan baik.

Perkembangan Ekonomi: Pasar, Koperasi, BUM Desa, Toko, Warung Makan. Perkembangan ekonomi di Dusun Suruh dapat berkembang ketika Pasar, Koperasi, Badan Usaha Milik Desa (BUM Desa), Toko, dan Warung Makan dapat berjalan dengan lancar.

Hasil penelitian tersebut ditemukan bahwa, dengan adanya Sumur Bor di Dusun Suruh sangat bermanfaat bagi Usaha Mikro Kecil dan Menengah karena Dusun Suruh merupakan dusun yang tandus dengan mengandalkan air hujan dan sering terjadi kekuarangan air ketika musim kemarau, sehingga baik tanah pertanian, perkebunan dan budidaya alam lainnya memerlukan pangairan yang dihasilan dari Sumur Bor sebagai pangairan tambahan ketika tidak turun hujan. Dengan adanya sumur bor teraebut keadaan ekonomi semakin berkembang, itu artinya Pembangunan Ekonomi di Dusun Suruh semakin bagus ketika dihadrkan sumur bor.

\section{KESIMPULAN DAN SARAN \\ Simpulan}

Berdasarkan hasil analisis tersebut ditemukan bahwa, dengan adanya Sumur Bor di Dusun Suruh sangat bermanfaat bagi Usaha Mikro Kecil dan Menengah (UMKM) karena Dusun Suruh merupakan dusun yang tandus dengan mengandalkan air hujan dan sering terjadi kekuarangan air ketika musim kemarau, sehingga baik tanah pertanian, perkebunan dan budidaya alam lainnya memerlukan pangairan yang dihasilan dari Sumur Bor sebagai pangairan pengganti air hujan pada saat jatuhnya musim kemarau. Dengan UMKM yang telah berjalan dengan lancar maka keadaan ekonomi semakin membaik, itu artinya Pembangunan Ekonomi berjalan dengan lancar dan sukses tentunya.

\section{Saran}

Saran-saran yang dapat Penulis sampaikan terkait dengan hasil penelitian pada Usaha Mikro Kecil dan Menengah (UMKM), yaitu:

Dengan adanya Sumur Bor tersebut maka para pelaku Usaha Mikro Kecil Menengah (UMKM) dapat memanfaatkan dengan sebaik-baiknya sehingga Sumur Bor yang telah disediakan oleh para investor dan donatur betul-betul dapat mengembangkan Usaha Mikro Kecil dan Menengah (UMKM) di Dusun Suruh. Mudah-mudahan di Dusun Suruh semakin banyak Sumur Bor yang dibuat oleh investor atau pemrakarsa-pemrakarsa sehingga Dusun Suruh dapat terpenuhi pengairan dengan menggunakan Sumur Bor sehingga Usaha Mikro Kecil dan Menengah (UMKM) di dusun tersebut dapat meningkat dan maju. Dengan majunya UMKM maka keadaan Ekonomi di Dusun Suruh akan semakin membaik sehingga diwilayah tersebut akan menjadi daya tarik warga dalam usia produktif. Karena selama ini penduduk usia produktif cenderung ingin merubah nasib di daerah laian ketika menganggap bahawa Dusun Suruh dianggap dusun yang kurang mempunyai potensi.

\section{DAFTAR PUSTAKA}

Giovana Asti, Eka , 2018, “Analisis Pengaruh Mental Wirausaha Dan Kreativitas Terhadap Motivasi Berwirausaha Pada Pengusaha Rumah Makan Di Kelurahan Padurenan, Bekasi”, Jurnal Pengembangan Wiraswasta Vol 20 No. 03, STIE IPWI Jakarta,

http://bappeda.gunungkidulkab.go.id/2021/01/ berjuang-menyediakan-akses-air-minum-layakdi-kalurahan-hargomulyo-kapanewongedangsari/

h t t p s : / / w w w. g o o g l e.c o m / search?q=UMKM+SURUH+HARGOMULYO

https://www.kompas.com/skola/read/2021/01/06/ 190000369/kerajinan-dari-bahan-limbahkertas?page $=$ all. 
https://www.hargomulyo-gedangsari.desa.id/first/ artikel/137

Nitisusastro, Mulyadi, 2012, Kewirausahaan dan Manajemen Usaha Kecil, Jakarta

Siagian, 2003, Manajemen Sumber Daya Manusia, Bumi Aksara, Jakarta.

Sugiyono. 2015, Prosiding Seminar Nasional Pendidikan Ekonomi \& Bisnis, Fakultas

Keguruan dan Ilmu Pendidikan Universitas Sebelas Maret Surakarta,.

Sugiyono, 2015 , “ Analisis Penyediaan Dan Penggunaan Modal Kerja UMKM (Usaha Mikro, Kecil Dan Menengah)" Fakultas Keguruan dan Ilmu Pendidikan Universitas Sebelas Maret, Surakarta'

Sugiyono, 2017, Statistik untuk Penelitian, Alfabeta, Bandung.
Sukirman, 2017 "Jiwa Kewirausahaan Dan Nilai Kewirausahaan Meningkatkan Kemandirian Usaha Melalui Perilaku Kewirausahaan”, Jurnal Ekonomi dan Bisnis, Volume 20 No 1.

Widodo, 2018, Hubungan Motivasi Kepala Sekolah terhadap Kinerja Guru pada SMK YAJ Depok Jawa Barat, Prosiding Manajerial \& Kewirausahaan Call for Paperrs 3rd \& Seminar Nasional, penelitian Manajemen dan Kewirausahaan di Era Digital, Volume 3, Nomor 01, Agustuts 2018, IPWIJA Jakarta

Widodo dan Indri Astuti, 2017, Motivasi Kepala Desa dalam Pembangunan Ekonomi (Studi Kasus pada Wilayah Desa Hargomulyo, Gedangsari, Gunung Kidul), Equilibrium Point, Jurnal Manajemen dan Bisnis, Volume 2, Nomor 2, Agustus 2018, ISSN 2598-4837, STIMA IMMI, Jakarta. 